\title{
DESAIN TAMAN EDUWISATA BERBASIS AGRO
}

\section{Made Agus Dharmadiatmika ${ }^{*}$ Cokorda Gede Alit Semarajaya ${ }^{2}$, Naniek Kohdrata ${ }^{3}$ 1,2,3Program Studi Arsitektur Pertamanan, Fakultas Pertanian, Universitas Udayana e-mail: *1 dharmadiatmika@unud.ac.id}

\begin{abstract}
Abstrak_Taman oleh masyarakat awam dikenal sebagai suatu tempat yang indah dan penuh dengan tanaman berbunga. Taman merupakan tempat berekreasi dan melepas lelah. Penelitian tentang Desain Taman Eduwisata Berbasi Agro ini merupakan suatu upaya untuk menunjukkan bahwa dengan ilmu arsitektural lanskap, suatu lahan dengan fungsi pendidikan dan penelitian dapat pula memberikan nilai rasa estetika bagi pengguna dan pengunjung. Desain taman yang dilakukan pada kondisi lingkungan kebun dapat dikreasikan sedemikian rupa untuk memberikan manfaat rekreatif dan sekaligus edukatif. Berbagai fasilitas pendukung tambahan tentu perlu disediakan dan diadakan untuk mencapai tujuan tersebut. Area penerimaan yang memiliki ciri khas, tempat parkir yang tertata, sirkulasi yang nyaman, dan juga fasilitas multifungsi merupakan beberapa fasilitas yang didesain untuk ada di kebun percobaan. Bentuk-bentuk yang indah dan menarik dibuat untuk memberi kesan estetik bagi pengunjung, terutama dengan tujuan untuk mengoptimalisasi pemanfaatan kebun FP. Desain yang menarik dan mengesankan bahwa kebun percobaan adalah tempat wisata dan rekreasi dibuat dengan maksud untuk menciptakan kesan dan juga menarik minat masyarakat umum bahwa kebun tidak harus selalu identik dengan tanah yang kotor dan berlumpur. Kebun percobaan juga dapat indah, menarik, dan unik. Sebagai kebun percobaan yang dikelola oleh Fakultas Pertanian Universitas Udayana, desain taman eduwisata berbasis agro ini akan memberikan wajah baru dan perspektif baru bagi pengguna, khususnya civitas akademika Fakultas Pertanian Unud.
\end{abstract}

Kata kunci: Kebun Percobaan; Kebun; Edu-Pariwisata; Kebun Berbasis Agro.

\begin{abstract}
People familiar with a garden as a beautiful place, full of pretty blooming flowers. That is an ideal picture of a garden known by people in general. It is also a place for recreation and being refresh. A research on designing an agro-based edu-tourism garden is an effort to show that using landscape architectural point of view, a piece of land with education and research functions can also provide a sense of aesthetic value for users and visitors. Garden design that is carried out on a kebun environment setting can be created in such a way as to provide recreational and educational benefits as well. Some additional supporting facilities will be needed to achieve the goal. Some facilities that are planned to be designed in Faculty of Agriculture research center kebun will be a unique design of welcome area, a well-organized parking area, good circulation, and also some multi-function facilities to support activities and programs of kebun. In this case, kebun shall be understand as an experimental garden. An interesting and beautifully design experimental garden will enhance the aesthetic value of a place and should impress visitors. It will also draw public impression away from a kebun that deals with dirt and muddy soil to a place that suits for recreation and education as well. Experimental gardens can be beautiful, interesting, and unique as well. As an experimental garden managed by the Faculty of Agriculture, Udayana University, the design of this agro-based edu-tourism experimental garden will provide a new face and perspective for visitors and users, especially the students and faculties.
\end{abstract}

Keywords: Experimental Garden; Garden; Edu-Tourism; Agro-Based Garden.

\footnotetext{
${ }^{1}$ Program Studi Arsitektur Pertamanan, Fakultas Pertanian, Universitas Udayana

${ }^{2}$ Program Studi Arsitektur Pertamanan, Fakultas Pertanian, Universitas Udayana

${ }^{3}$ Program Studi Arsitektur Pertamanan, Fakultas Pertanian, Universitas Udayana
} 
I Made Agus Dharmadiatmika *,

Cokorda Gede Alit Samarajaya, Naniek Khodrata

\section{PENDAHULUAN}

Kota-kota besar maupun sedang di Indonesia saat ini telah mengalami kompetisi yang tinggi dalam pemanfaatan ruang. Kota Denpasar dan Badung merupakan kota dan kabupaten di pulau Bali yang mengalami dan merasakan dampak urbanisasi yang terjadi karena daya tarik pariwisat Bali. Tuntutan tempat tinggal untuk populasi yang meningkat menyebabkan lahan menjadi sangat berharga dan mahal. Sebagian besar lahan di perkotaan berubah menjadi tempat hunian dan fasilitas-fasilitas pelayanan pendidikan, kesehatan, perdagangan, pemerintahan, dan hiburan yang didominasi oleh massa bangunan. Lahan persawahan kota jelas menjadi barang langka, demikian pula ruang-ruang terbuka hijau yang sejatinya penting bagi sebuah kota.

Fakultas Pertanian Universitas Udayana memiliki sebidang tanah seluas 1,8 hektar yang di Jalan Pulau Moyo, Denpasar yang difungsikan sebagai kebun percobaan dan penelitian bagi civitas akademika Unud, khususnya Fakultas Pertanian. Lahan yang cukup luas tersebut kiranya dapat dimaksimalkan penggunaannya tidak hanya bagi internal pendidikan dan penelitian civitas Fakultas Pertanian. Proses dan aktivitas yang terjadi di dalam kebun riset dan pendidikan tersebut dapat pula kiranya diketahui dan dipromosikan kepada masyarakat umum. Hal ini sejalan dengan semangat Tri Dharma Perguruan Tinggi yang mencakup aspek pendidikan, penelitian, dan pengabdian. Kebun Percobaan Fakultas Pertanian (KPFP) memiliki lokasi dan fungsi yang strategis di wilayah dengan kondisi lingkungan perkotaan. KPFP merupakan salah satu bentuk ruang terbuka hijau yang berfungsi produksi dalam bingkai pendidikan dan penelitian. Tahun 2017 melalui Hibah Pengabdian Udayana dengan judul Kenal Kebun untuk Anak Usia Dini telah menghasilkan model program untuk optimalisasi pemanfaatan kebun. Kekurangan yang muncul saat itu adalah masalah infrastruktur yang tidak reprsentatif untuk mendukung pengunjung masyarakat umum, seperti tempat berkumpul yang memiliki naungan, tempat bilas yang aman nyaman, serta tempat parkir. Optimalisasi pemanfaatan dapat dilakukan melalui penelitian berupa desain fasilitas pendukung yang sesuai dengan kondisi KPFP. Desain yang sesuai untuk mengantisipasi dan mengakomodasi pengguna non civitas akademika perlu dibuat sehingga ruangruang yang ada di KPFP dapat dimanfaatkan secara maksimal. Fasilitas tempat berkumpul dengan peneduh yang dapat menampung 100 - 200 perlu dikreasikan dan didesain. Demikian pula masalah parkir kendaraan perlu dicarikan solusinya.

\section{METODE}

Penelitian direncanakan akan dilakukan dalam waktu 8 bulan. Lokasi penelitian adalah Kebun Percobaan Fakultas Pertanian Universitas Udayana di Jalan Moyo Denpasar. Penelitian yang berupa desain rancang bangun taman untuk lanskap kebun percobaan FP Unud adalah penelitian metode survei dengan analisa deskriptif. Pengumpulan data dilakukan dengan teknik survei untuk memperoleh data primer dan sekunder. Tahapan proses desain mengikuti metode Bell (2005) yang menggunakan konsep pendekatan desain untuk rekreasi ruang luar. Proses desain dimulai dari tahap persiapan, penilaian permintaan pengguna, tahap survei/inventarisasi, analisis, desain, dan desain detail. Tahap penilaian permintaan pengguna akan dipergunakan data yang diperoleh dari hasil pengabdian-penelitian "Kenal Kebun pada Anak Usia Dini” (Semarajaya et al. 2017). Data yang diinventarisasi berupa data biofisik dan sosial. Data biofisik meliputi data dari aspek tanah, iklim, hidrologi, vegetasi, dan satwa. Data sosial akan diambil dari sampel responden dengan tipe

$\underset{\sim}{\sim}$ purposive sampling. Sampel responden terdiri dari pengelola kebun, pegawai kebun, serta dosen N 
I Made Agus Dharmadiatmika *, Cokorda Gede Alit Samarajaya, Naniek Khodrata

dan mahasiswa pengguna kebun. Tahapan analisis dilakukan melalui studi pustaka, juga mengacu pada hasil penelitian "Rencana Lansekap Wisata Edutani di Kebun Percobaan Fakultas Pertanian Universitas Udayana” (Semarajaya et al. 2016), dan observasi termutakhir di lapang saat penelitian ini dilakukan untuk melengkapi analisa. Tahap desain merupakan proses kreatifitas logis untuk mensintesa hasil dari tahapan analisa dalam bentuk ide desain yang diterjemahkan dalam bentuk grafis. Proses ini mencakup pembuatan konsep desain dan pengembangan desain.

\section{HASIL DAN PEMBAHASAN}

\section{A. Taman Sebagai Ruang Terbuka Hijau Publik}

Secara definitif, Ruang Terbuka Hijau (RTH) dimaknai sebagai bagian dari ruang-ruaang terbuka suatu wilayah perkotaan dengan komponen tumbuhan, tanaman, dan vegetasi guna mendukung manfaat langsung dan/atau tidak langsung yang dihasilkan dari RTH kota dalam hal keamanan, kenyamanan, kesejahteraan, dan keindahan kota (Laboratorium Perencanaan Lanskap Departemen Arsitektur Lanskap Fakultas Pertanian 2008). Moughtin dan Shirley (2005) menyatakan bahwa gerakan "Hijau" sebenarnya telah dimulai sejak sekitar akhir tahun 1930an oleh Mumford dalam tulisannya Rise and Fall of Megalopolis, kemudian muncul Ebenezer Howard dengan konsepnya Garden City sekitar petengah tahun 1960an, dan di akhir tahun 60an terbit karya akademis yang mendunia dari Ian McHarg, yaitu Design with Nature. selanjutnya Pemerintah Indonesia mengadopsi konsep hijau untuk tata ruang wilayah dengan mengesahkan UU RI nomor 26 tahun 2007 tentang Penataan Ruang yang memuat ketentuan perencanaan tata ruang wilayah kota untuk menyediakan ruang terbuka hijau.

Pengertian ruang publik menurut Wolley (2005) adalah ruang-ruang, seperti tamantaman kota dan plaza, yang dapat diakses oleh masyarakat umum (publik). Secara lebih spesifik Walzer (dalam Wolley, 2005) mengatakan bahwa ruang publik adalah ruang dimana kita berbagi tempat dengan orang-orang asing yang tidak kita kenal, orang yang bukan keluarga, teman, ataupun rekan kerja. Pembahasan ruang publik dalam konteks RTH dapat mengacu pada UU No. 26 tahun 2007 tentang Tata Ruang yang mendeskripsikan ruang terbuka hijau publik adalah RTH yang dimiliki dan dikelola oleh pemerintah daerah kota yang digunakan untuk kepentingan masyarakat umum. Sedangkan Sejarah perkembangan desain taman menurut keilmuan arsitektur lanskap secara umum mengenal empat konsep taman. Konsep-konsep desain taman tersebut ada yang masih dapat terlacak secara fisik, namun tidak sedikit pula yang diketahui dari catatan sejarah (Kohdrata 2017). Hal ini juga didukung oleh pernyataan Dharmadiatmika (2017) yang menyatakan RTH Publik mampu mengakomodasi fungsi ekologis, fungsi estetika, fungsi ekonomi, fungsi sosial dan budaya

\section{B. Kondisi Umum}

Kebun percobaan fakultas pertanian Universitas Udayana, terletak di Kelurahan Pedungan, Kecamatan Denpasar Selatan, Provinsi Bali. Kebun percobaan fakultas pertanian (KPFP) memiliki luas 1.8 Ha. Secara geografis terletak pada koordinat 8042'21"LS dan 115012'58"BT. KPFP berada pada ketinggian antara 0 - 25 mdpl (BPS Kota Denpasar, 2016). Kondisi topografi relative datar yaitu berkisar antara 0-8\% dengan jenis tanah latosol coklat kekuningan (Bappeda, 2016). Kondisi tersebut menjadikan KPFP mampu memfasilitasi kegiatan pertanian didalamnya. Secara fisik KPFP berbatasan dengan :
Sebelah Utara
: Komplek perumahan
Sebelah Timur
: Komplek pedagangan dan jasa
Sebelah Selatan
: Gedung perkantoran 
I Made Agus Dharmadiatmika *, Cokorda Gede Alit Samarajaya, Naniek Khodrata

Sebelah Barat

: Pemukiman penduduk

Orientasi lokasi tapak tempat dilakukannya penelitian dapat dilihat pada Gambar 1

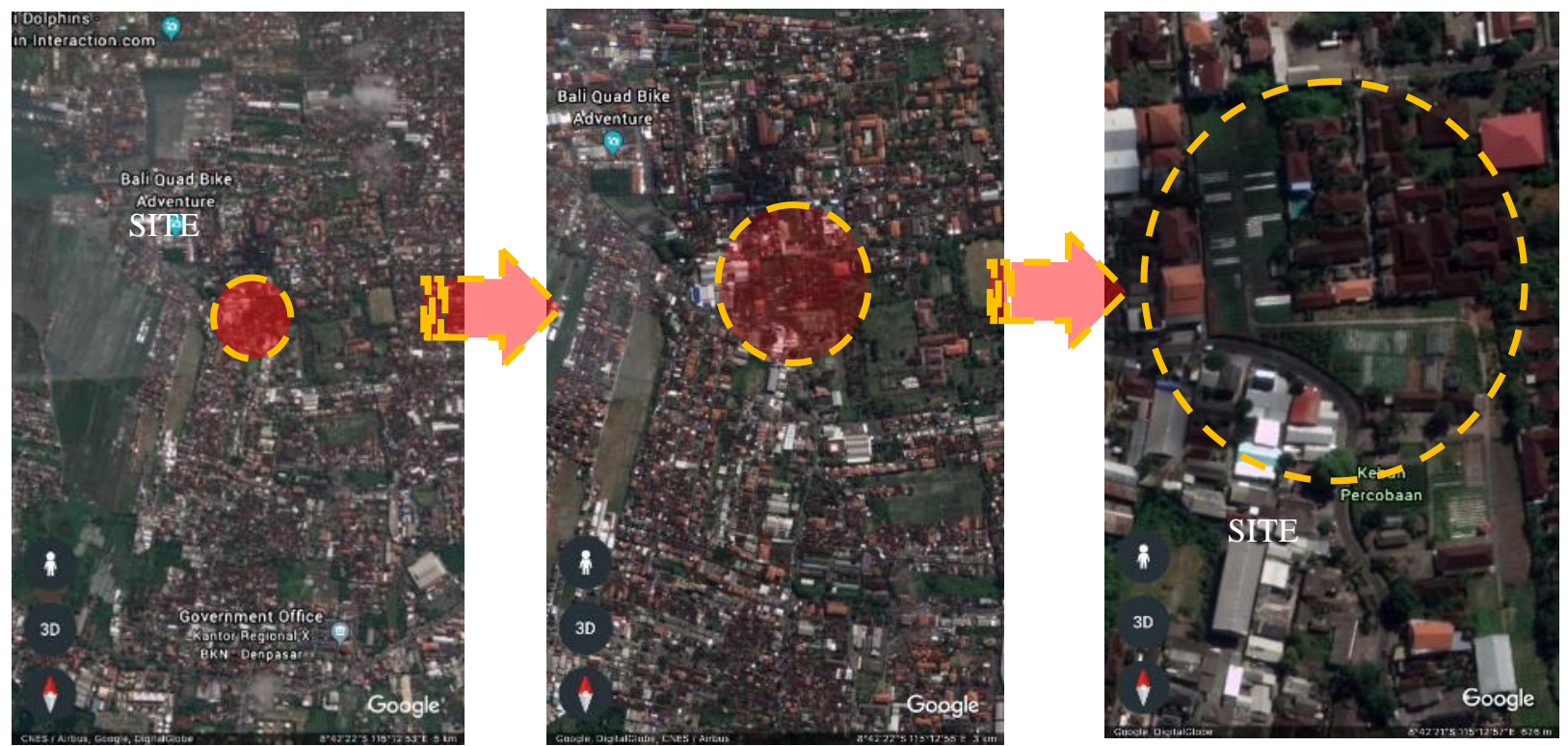

Gambar 1. Lokasi Kebun Percobaan Fakultas Pertanian (KPFP) Unud Sumber: Google Earth,

\section{Kondisi Iklim}

Kondisi iklim merupakan faktor penting dalam kegiatan pertanian di KPFP karena akan berdampak langsung terhadap jenis dan pertumbuhan tanaman. Berasarkan data BPS Kota Denpasar (2017), Suhu rata-rata Kota Denpasar adalah 27,70C dengan kelembaban udara ratarata adalah 79\%, Curah hujan sepanjang tahun adalah 2323,4 mm, kecepatan angina 6 knot dan intensitas penyinaran matahari adalah 50\%. Kondisi curah hujan bulanan menunjukkan bahwa curah hujan di wilayah Denpasar cenderung berada dalam kisaran kategori rendah sedang. Hal ini menguntungkan dari segi rencana pemanfaatan KPFP sebagai tujuan rekreasi agro-eduwisata. Namun dari aspek budidaya tanaman memerlukan perhatian lebih pada sistem pengairan, terutama pada saat musim kering. Sementara dari aspek rekreasi memerlukan shelter atau tempat-tempat aktifitas yang memiliki naungan. Kelembaban cukup tinggi sehingga aktifitas ruang luar untuk kepentingan rekreasi-wisata perlu memperhatikan faktor kenyamanan pengunjung.

\section{Kondisi Vegetasi}

Sesuai dengan fungsinya, KPFP didominasi oleh tanaman dengan jenis-jenis tanaman produksi diantaranya seperti buah, sayuran, tanaman kacang-kacangan, serta beberapa jenis bunga yang banyak dipakai sarana upacara dalam agama Hindu di Bali. Selain itu KPFP juga dilengkapi dengan sejumlah tanaman sebagai penunjang fungsi estetika. Adapaun sejumlah tanaman eksisting yang ada di KPFP dapat dilihat pada Tabel 1.

Tabel 1. Tanaman Dijumpai di KPFP

\begin{tabular}{lllll}
\hline NO & \multicolumn{1}{c}{ TANAMAN BUAH } & TANAMAN OBAT & \multicolumn{1}{c}{ TANAMAN UMBI } & \multicolumn{1}{c}{ TANAMAN HIAS } \\
\hline 1 & Belimbing (Averrhoa & Lidah buaya (Aloe \\
& carambola L.) & Ketela pohon & Agave (Agave angustifolia \\
& & vera (L.) Burm. f.) & $\begin{array}{l}\text { (Manihot esculenta } \\
\text { Crantz - cassava) }\end{array}$ & Haw) \\
2 & $\begin{array}{l}\text { Limau (Psidium guajava } \text { L. } \\
\text { - guava) }\end{array}$ & $\begin{array}{l}\text { Kayu manis } \\
\text { (Cinnamomum }\end{array}$ & $\begin{array}{l}\text { Bawang merah } \\
\text { (Allium cepa var. }\end{array}$ & Andong merah (Cordyline \\
& & & & fruticosa (L.) A. Chev)
\end{tabular}

$N$ 


\begin{tabular}{|c|c|c|c|c|}
\hline NO & TANAMAN BUAH & TANAMAN OBAT & TANAMAN UMBI & TANAMAN HIAS \\
\hline & & $\begin{array}{l}\text { burmannii (Nees \& } \\
\text { Th. Nees) Nees ex } \\
\text { Blume - Padang } \\
\text { cassi) }\end{array}$ & aggregatum) & \\
\hline 3 & $\begin{array}{l}\text { Jeruk nipis (Citrus } \\
\text { aurantifolia) }\end{array}$ & $\begin{array}{l}\text { Genitri/jenitri } \\
\text { (Elaeocarpus } \\
\text { ganitrus Roxb.) }\end{array}$ & $\begin{array}{l}\text { Kentang (Solanum } \\
\text { tuberosum) }\end{array}$ & Kamboja (Plumeria alba L.) \\
\hline 4 & $\begin{array}{l}\text { Mangga (Mangifera indica } \\
\text { L.) }\end{array}$ & $\begin{array}{l}\text { Kemenyan (Styrax } \\
\text { benzoin Dryand.) }\end{array}$ & $\begin{array}{l}\text { Talas (Colocasia } \\
\text { esculenta) }\end{array}$ & $\begin{array}{l}\text { Kembang sepatu (Hibiscus } \\
\text { rosa-sinensis L.) }\end{array}$ \\
\hline 5 & Pisang (Musa L.) & $\begin{array}{l}\text { Jarak (Jatropha } \\
\text { curcas L.) }\end{array}$ & & $\begin{array}{l}\text { Seruni rambat } \\
\text { (Sphagneticola trilobata (L.) } \\
\text { Pruski) }\end{array}$ \\
\hline 6 & $\begin{array}{l}\text { Buah naga (Hylocereus } \\
\text { undatus (Haw.) Britton \& } \\
\text { Rose) }\end{array}$ & & & $\begin{array}{l}\text { Waru (Hibiscus tiliaceus L. - } \\
\text { sea hibiscus) }\end{array}$ \\
\hline 7 & $\begin{array}{l}\text { Jambu (Syzygium aqueum } \\
\text { (Burm. f.) Alston) }\end{array}$ & & & $\begin{array}{l}\text { Ketapang kencana } \\
\text { (Terminalia mantaly L. - } \\
\text { India almond) }\end{array}$ \\
\hline 8 & Papaya (Carica papaya L.) & & & $\begin{array}{l}\text { Kelapa sawit (Elaeis } \\
\text { guineensis Jacq. - African oil } \\
\text { palm) }\end{array}$ \\
\hline 9 & $\begin{array}{l}\text { Cabai (Capsicum annuum } \\
\text { L.) }\end{array}$ & & & $\begin{array}{l}\text { Palem ekor tupai (Wodyetia } \\
\text { bifurcate) }\end{array}$ \\
\hline 10 & Melon (Cucumis melo L) & & & $\begin{array}{l}\text { Pangkas kuning (Duranta } \\
\text { L.) }\end{array}$ \\
\hline 11 & $\begin{array}{l}\text { Tomat (Solanum } \\
\text { lycopersicum) }\end{array}$ & & & $\begin{array}{l}\text { Reulia ungu (Ruellia } \\
\text { malacosperma) }\end{array}$ \\
\hline 12 & $\begin{array}{l}\text { Terong (Solanum } \\
\text { melongena) }\end{array}$ & & & $\begin{array}{l}\text { Walisongo (Annonaceae - } \\
\text { Custard-apple family) }\end{array}$ \\
\hline 13 & $\begin{array}{l}\text { Mengkudu (Morinda } \\
\text { citrifolia L.) }\end{array}$ & & & $\begin{array}{l}\text { Sansivera (Sansevieria } \\
\text { cylindrica Bojer ex Hook.) }\end{array}$ \\
\hline
\end{tabular}

Sumber: Data inventarisasi penelitian,

\section{E. Analisis Tata Guna Lahan KPFP}

Kondisi tata guna lahan di KPFP tersusun atas pengelompokan yang dikaitkan dengan sistem sirkulasi. Secara umum pembagian tata guna lahan dapat dikategorikan kedalam tiga zona, yaitu zona praktikum, zona penelitian dan zona pengelolaan. Penjabaran terinci dari fungsi dan aktivitas yang direncanakan dalam masing-masing zona dapat diikuti pada penjelasan berikut ini.

1. Zona praktikum merupakan area yang diperuntukkan guna mendukung kegiatan pembelajaran mahasiswa selain yang telah diperoleh di kampus bukit Jimbaran dan kampus sudirman. adapun fasilitas antara lain : rumah kaca satu sampai dengan tiga, stasiun klimatologi, ruang display, ruang kelas, studio arsitektur lanskap.

2. Zona penelitian merupakan area yang diperuntukkan guna mendukung kegiatan penelitian bagi civitas akademika dilingkungan fakultas pertanian selain lab-lab yang dimiliki pada masing-masing program studi. adapun fasilitas pada zona penelitian antara lain: lab. kultur jaringan, rumah jamur, inkubator agribisnis, pabrik takino filter, lahan pertanian block $\mathrm{A}$ sampai dengan block I. 
3. Zona pengelola merupakan area yang diperuntukkan bagi pengelola KPFP guna menunjang kebiatan praktikum, penelitian, pengabdian, rekreasi dan penjualan asil-asil pertanian. failitas penunjang kegiatan ini adalah ruang pertemuan/kantor, gudang, gazebo, parkir dan toilet.

Perencanaan dan pengaturan tata guna lahan dan fasilitas yang ada di KPFP secara lebih detail dapat dilihat pada Gambar 2.

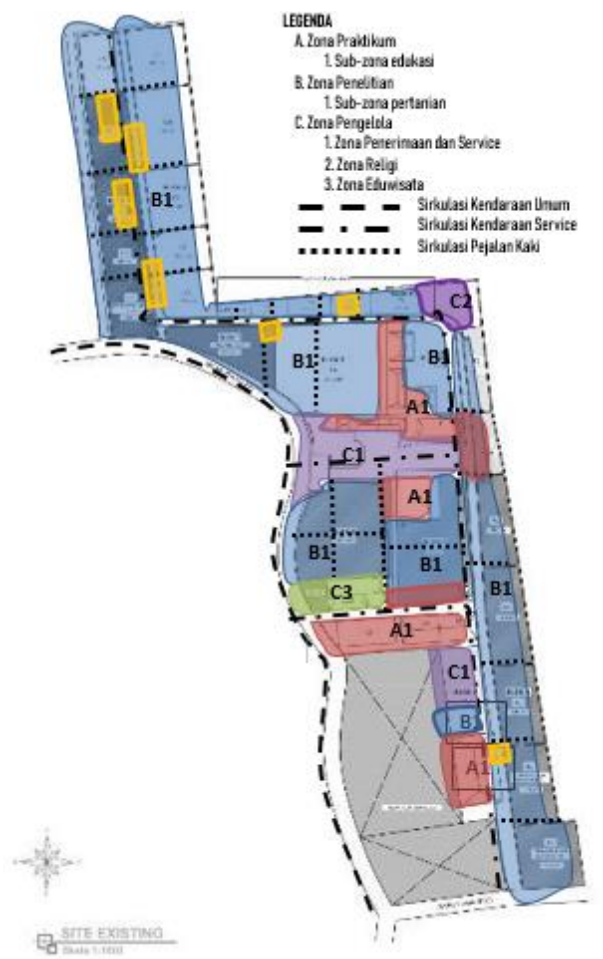

Gambar 2. Peta analisa Tata Guna Lahan KPFP

\section{F. Optimalisasi Fungsi, Fasilitas, dan Efektifitas Sirkulasi}

Peningkatan intensitas pemakaian oleh mahasiswa FP di kebun percobaan menimbulkan permasalahan parkir untuk kendaraan bermotor. Hal ini terutama belum terdapat rambu-rambu yang jelas untuk lokasi parkir kendaraan. Upaya yang dilakukan pengelola kebun baru sebatas memberitahu mahasiswa untuk memarkir kendaraan dengan rapi. Hal ini berimbas pada potensi konflik sirkulasi, baik untuk pejalan kaki maupun manuver kendaraan. Pada saat diadakan kegiatan khusus di KPFP, seperti pengabdian yang mengundang masyarakat maupun kegiatan yang melibatkan seluruh civitas akademika FP, masalah utama adalah kurangnya lahan parkir dan juga lalu lintas parkir yang berantakan. Untuk lokasi parkir pada waktu-waktu khusus dapat diatasi dengan meminjam lokasi di Balai Karantina Tanaman. Walaupun demikian, hal ini tetap tidak menyelesaikan masalah ketidakteraturan parkir yang terjadi.

Permasalahan parkir dan sirkulasi perlu diselesaikan sebagai satu kesatuan terpadu untuk memaksimalkan pemanfaatan lahan yang ada tanpa mengorbankan lahan produktif yang dapat dipergunakan untuk bertanam. Jalan-jalan yang dapat dilalui oleh kendaraan dapat dimaksimalkan sebagai tempat parkir mobil/motor dalam kesempatan-kesempatan khusus. Jalan-jalan setapak yang memisahkan petak-petak penanaman dapat dimaksimalkan sebagai 
jalur pejalan kaki. Pemberian batas dan rambu parkir menjadihal penting yang perlu dilakukan di KPFP untuk menciptakan keteraturan parkir dan kelancaran sirkulasi. Perlu dibuat juga di beberapa titik sebagai tempat manuver kendaraan atau kendaraan berpapasan karena KPFP juga memiliki kendaraan operasional angkut semacam bentor (becak motor) dengan dimensi $3360 \times 1330$ x $1330 \mathrm{~mm}$ dan radius putar tertentu. Fasilitas berikut yang penting adalah toilet, karena dengan peningkatan jumlah pengguna maka dengan otomatis akan terjadi peningkatan penggunaan sarana kebersihan tersebut. Saat ini, toilet yang berfungsi hanya satu unit, terletak dekat kantor pengelola (sebelah utara). Kondisi fasilitas cukup memadai, namun tidak dari segi kuantitas karena dengan intensitas mahasiswa yang berpraktikum maupun kuliah di KPFP maka terjadi penumpukan pemakaian. Penambahan toilet perlu dilakukan di area bagian selatan tapak untuk mendukung aktifitas di area tersebut.

\section{G. Analisa Kebutuhan Kawasan KPFP}

Kebutuhan berdasarkan fungsi kegatan pada kawasan ini sebagai kawasan eduwisata adalah sebagai berikut:

1. Fungsi praktikum

Kegiatan praktikum merupakan fungsi utama di KPFP yang dilakukan oleh dosen untuk mahasiswa sebgai penunjang teori yang telah diberikan. adapun alur kegiatan praktikum di KPFP dapat dilihat pada gambar 3.

2. Fungsi penelitian

Selain fungsi praktikum, kegiatan penelitian merupakan fungsi utama yang dilakukan di KPFP. Kegiatan penelitian dilakukan oleh dosen dan mahasiswa fakultas pertanian. KPFP memfasilitasi kegiatan penelitian selain yang dilakukan di laboratorium masing-masing prodi. kegiatan praktikum di KPFP dapat dilihat pada gambar 4.

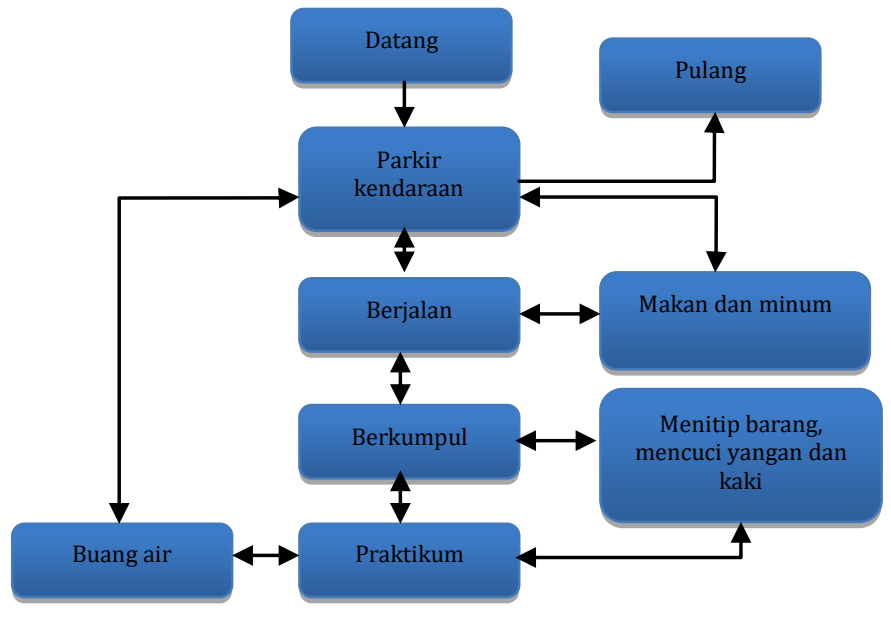

Gambar 3. Alur aktivitas praktikum di KPFP

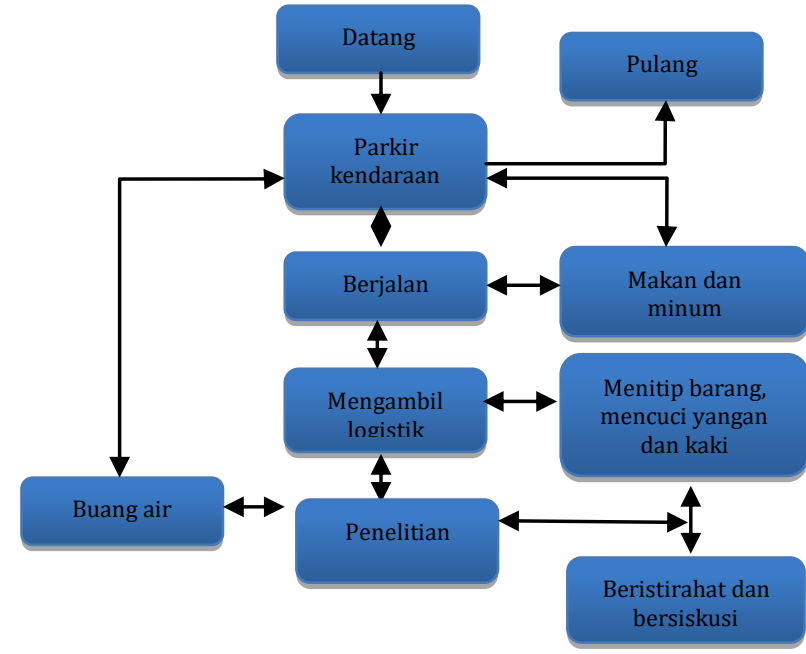

Gambar 4. Alur aktivitas penelitian 
I Made Agus Dharmadiatmika *,

Cokorda Gede Alit Samarajaya, Naniek Khodrata

\section{H. Tema dan Program Penataan}

Pendekatan tema yang digunakan dalam penataan KPFP sebagai kawasan eduwisata adalah sebagai berikut.

1. Pendekatan terhadap fungsi kawasan

Fungsi utama dari kawasan KPFP adalah sebagai kawasan yang mewadahi kegiatan civitas akademika dilingkungan Fakultas Pertanian guna melaksanakan kegiatan praktikum, pengabdian masyarakat dan penelitian. Seiring dengan meningkatnya kebutuhan rekreasi di kawasan perkotaan, maka dari itu berkembang penambahan fungsi eduwisata di KPFP diintroduksikan sebagai salah satu inovasi dari pemanfaatan KPFP dalam merespon perkembangan yang terjadi dalam masyarakat.

2. Pendekatan terhadap iklim dan lingkungan sekitar

Penataan KPFP, tidak hanya dilakukan penataan serta pengadaan bangunan dari segi estetika yang tinggi namun perancangan fasilitas yang direncanakan dapat diakomodasi sesuai dengan kondisi iklim lingkungan sekitar dengan tetap menjaga kelestarian lingkungan sekitar. Perancangan KPFP tetap mengacu kepada masterplan yang telah dimiliki dengan tetap mempertahankan bangunan eksisting. Penentuan tema rancangan dilakukan dengan mewujudkan kesatuan antar fasilitas yang ada. Selain itu penataan ruang terbuka juga perlu diperhatikan dengan menata tanaman-tanaman yang telah ada disekitar kawasan, sehingga terlihat lebih menyatu dengan lingkungan.

3. Pendekatan terhadap kondisi sosial dan budaya

Pendekatan ini dilakukan dengan menyesuaikan dengan ciri khas dan karakter bangunan dengan budaya yang terdapat disekitar kawasan. Berdasarkan karakter bangunan eksisting yang ada dan ciri khas arsitektur setempat, pendekatan rancangan arsitektur yang digunakan adalah Arsitektur Tradisional Bali sehingga penataan kawasan tetap menggunakan pakem-pakem dan langgam-langam Arsitektur Tradisional Bali, baik dari segi tampilan bangunan maupun pola penataan kawasannya. Dimana arsitektur tradisional Bali tidak hanya mementingkan tampilan bangunan dengan karakter dan sesuai peraturan yang berlaku di Bali, namun juga memperhatikan keselarasan antar bangunan dengan alam dan bangunan dengan manusianya.

Berdasarkan pendekatan yang dijabarkan di atas, maka tema yang digunakan dalam desain KPFP sebagai kawasan eduwisata adalah Sustainable Agriculture at Urban Setting.

\section{Program Penataan dan Desain}

Penatan dan desain dibuat dengan mengacu pada tema dan juga fungsi yang direncanakan. Bentuk-bentuk tampilan fisik yang diciptakan memuat unsur-unsur desain bercirikan arsitektur tradisional Bali dengan tetap mengedepankan asas fungsionalitas dan juga sentuhan modern untuk mendukung efektifitas program/kegiatan yang berlangsung di kebun KPFP. Penataan dan desain dilakukan di area kedatangan (entrance), area parkir, area tempat duduk (eating area), area internet (wif-fi area), area kantin dan dapur terbuka (kitchen garden and canteen), area sirkukasi dan taman, serta area drainase dan penyiraman. Prioritas program penataan dan desain dilakukan dengan mengacu pada konsep pengembangan KPFP ke masa depan dengan penambahan fungsi rekreasi sehingga konsep sirkulasi dirancang untuk memudahkan wisatawan menginterpretasikan obyek-obyek tanaman yang ada di KPFP. Sementara dari konsep kegiatan akan ditawarkan obyek (destinasi kecil) berupa fasilitasfasilitas pendukung produksi kebun, seperti green house, nursei, blok penanaman, blok 
I Made Agus Dharmadiatmika *, Cokorda Gede Alit Samarajaya, Naniek Khodrata

pembibitan, blok pengolahan berupa kuliner siap saji dengan knsep from garden to table. Di bebrapa tempat, sesuai dengan kondisi produksi kebun dapat dijadikan spot yang instragramble. Gambar Layout Plan untuk penataan dan Desain KPFP yang mendukung Tri Dharma Perguruan Tinggi dapat dilihat pada Gambar 5.

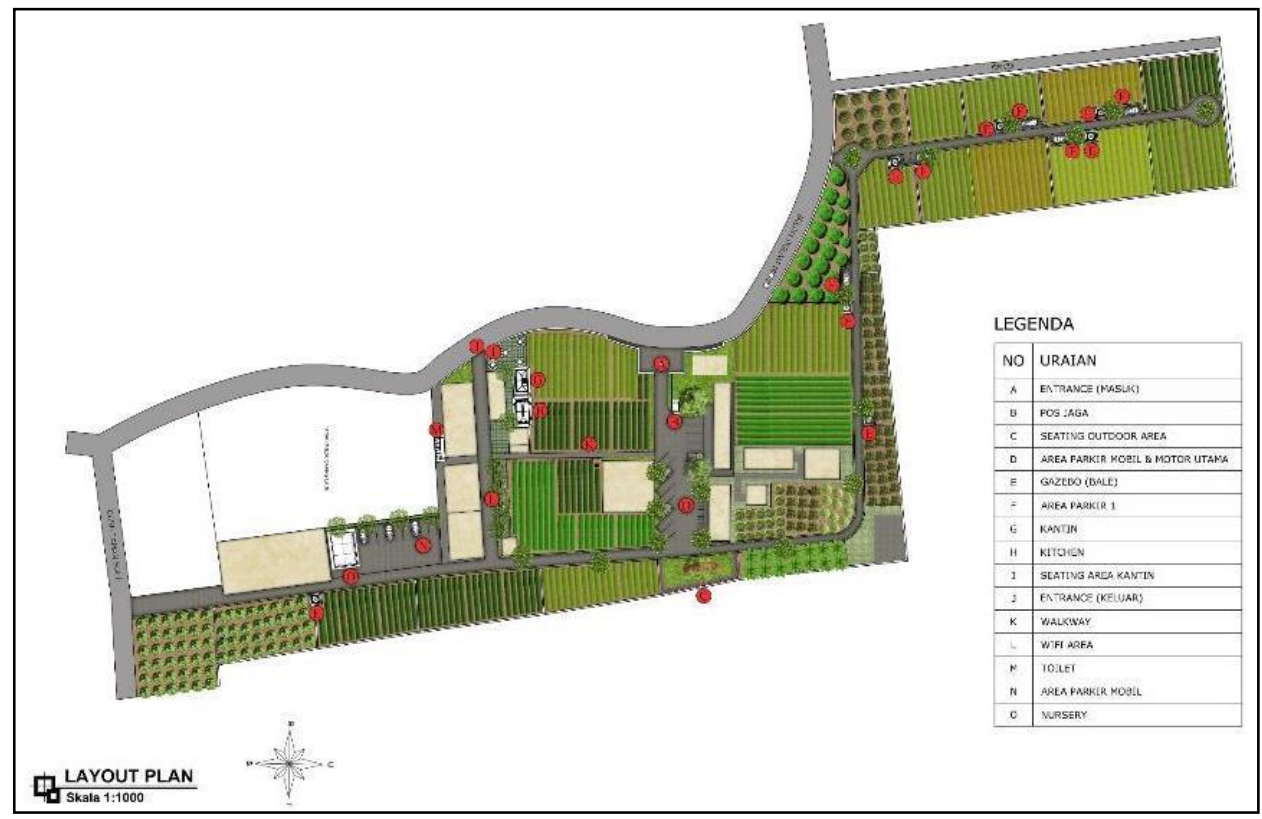

Gambar 5. Layout Plan KPFP

Gambar konsep desain pada penataan KPFP dapat dilihat selanjutnya pada ilustrasiilustrasi berikut ini.
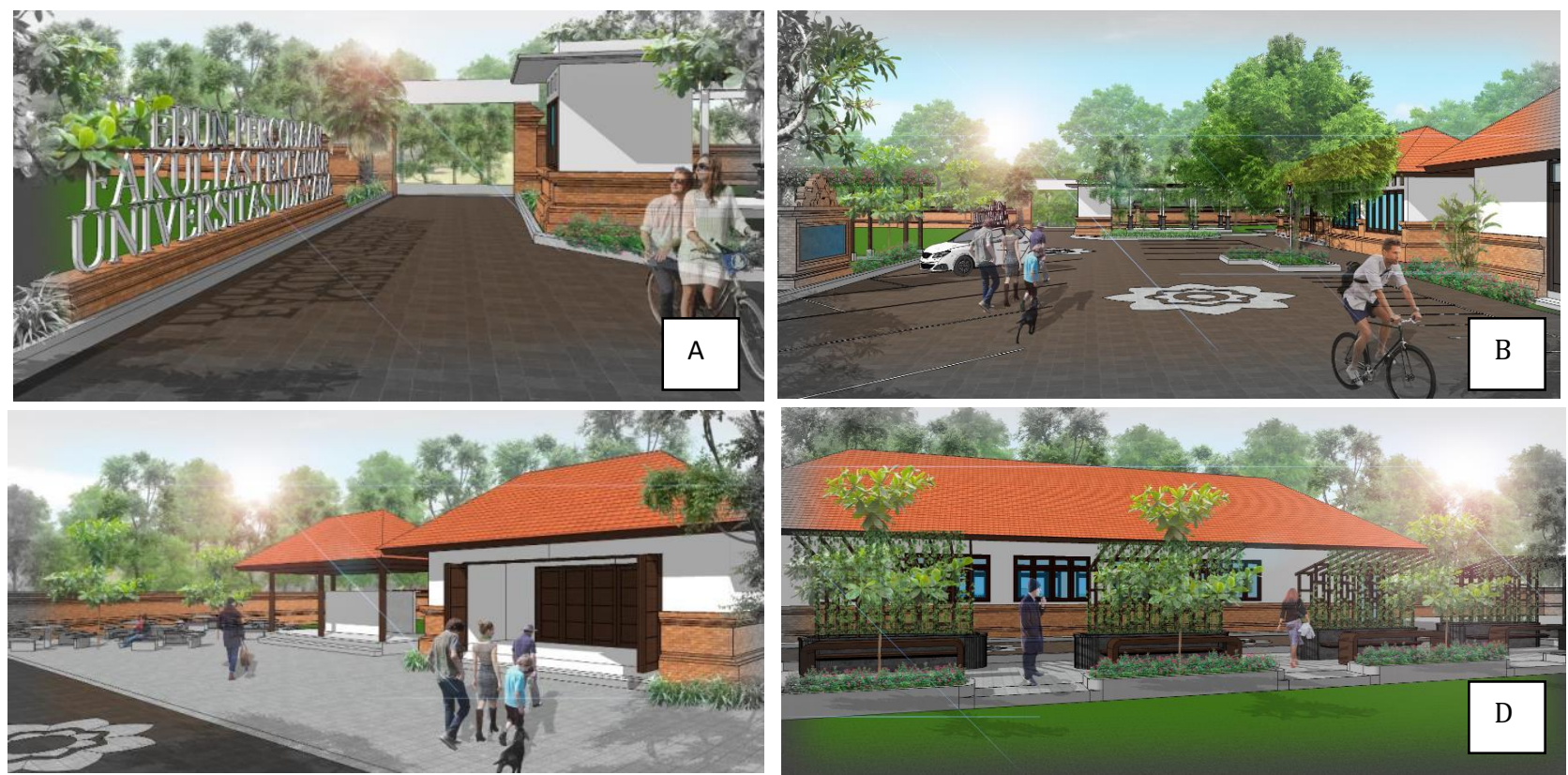

Gambar 6. A. Desain Main-Entrance KPFP, B. Desain area parkir, C. Desain kantin dan dapur terbuka (kitchen and canteen), dan D. Desain Area internet (wi-fi area) 


\section{KESIMPULAN}

Simpulan dari Desain Taman Eduwisata Berbasis Agro adalah kebun yang awalnya diperuntukkan untuk civitas akademika fakultas pertanian untuk fungsi penelitian dan pendidikan, ternyata dapat dioptimalkan pula untuk fungsi pengabdian. Optimalisasi ini dapat dilakukan dengan desain ruang dan bentuk yang menambah estetika kebun menjadi bernuansa taman. Fungsi utama sebagai tempat pendidikan dan penelitian tetap dapat dilakukan, sementara fungsi wisata edukasi juga dapat berjalan. Penambahan fungsi ini melalui perencanaan dan perancangan tapak kebun menjadikan kebun FP Unud lebih kaya aktivitas dan program yang dapat dilakukan di tapak tersebut. Unsur-unsur desain diolah untuk menghasilkan ruang dan tampilan struktur yang masih membawa ciri-ciri arsitektur tradisional Bali dengan pendekatan fungsi modern. Kebun percobaan Fakultas Pertanian Unud kiranya dapat menjadi suatu model bagi urban farming karena letaknya yang berada di lingkungan perkotaan. Desain kebun KPFP Unud merupakan kompromi dan adaptasi yang kreatif dari bentuk-bentuk arsitektural tradisional dengan fungsi-fungsi moden.

\section{DAFTAR REFERENSI}

Bell, S. 2005. “Design for Outdoor Recreation.” In Taylor \& Francis e-Library. London: Spoon Press.

Dharmadiatmika, I Made Agus. 2017. "Konsep Penataan Ruang Terbuka Hijau Publik Di Kota Kecamatan Mengwi, Kabupaten Badung, Provinsi Bali." JAL : Jurnal Arsitektur Lansekap 3 (2): 213-22.

Kohdrata, Naniek. 2017. Lanskap Taman Bali: Membaca dengan Pikiran dan Hati., issued 2017. Laboratorium Perencanaan Lanskap Departemen Arsitektur Lanskap Fakultas Pertanian, IPB. 2008. "Ruang Terbuka Hijau (RTH) Wilayah Perkotaan." Bali.

Moughtin, C, dan P Shirley. 2005. Urban Design: Green Dimensions. 2 ed. Burlington: Architectural Press.

Semarajaya, C.G.A, Nuniek Kohdrata, A.A.K. Krisnandika, L.S. Yusiana, dan A.A.A.W.S. Djelantik. 2017. Laporan Akhir Hibah Udayana Mengabdi Kenal Kebun pada Anak Usia Dini., issued 2017.

Semarajaya, C.G.A, Nuniek Kohdrata, K.A. Lila, A.A.G.D. Sudarsana, dan L.S. Yusiana. 2016. Laporan Akhir Hibah penelitian Unggulan Program Studi Rencana Lansekap Wisata Edutani di Kebun Percobaan Fakultas Pertanian Universitas Udayana., issued 2016.

Wolley, H. 2005. Urban Open Spaces. Francis: Taylor \& Francis e-Library. 